\title{
Sox-4 is a positive regulator of Hep3B and HepG2 cells' apoptosis induced by prostaglandin (PG)A $A_{2}$ and $\Delta^{12}-P J_{2}$
}

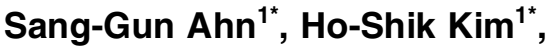 \\ Seong-Whan Jeong', Bo-Eun Kim', \\ Hyangshuk Rhim ${ }^{2}$, Jae-Yong Shim ${ }^{3}$, \\ Jin-Woo Kim ${ }^{2}$, Jeong-Hwa Lee ${ }^{1}$ and \\ In-Kyung Kim ${ }^{1,2,4}$ \\ ${ }^{1}$ Department of Biochemistry, \\ ${ }^{2}$ Research Institute of Molecular Genetics, \\ ${ }^{3}$ Department of Anesthesiology, College of Medicine, The Catholic \\ University of Korea, 505 Banpo-Dong, Socho-Gu, Seoul 137-701, \\ Korea \\ ${ }^{4}$ Corresponding Author:Tel, +82-2-590-1175; \\ Fax, +82-2-596-4435; E-mail, ikkim@ catholic.ac.kr \\ * These authors contributed equally to this work
}

Accepted 20 July 2002

Abbreviations: PG, Prostaglandin; HMG, high mobility group, Sox-4, Sry-HMG-box 4.

\begin{abstract}
We reported earlier that expression of Sox-4 was found to be elevated during prostaglandin (PG) A2 and $\Delta^{12}$ $P G J_{2}$ induced apoptosis in human hepatocarcinoma Hep3B cells. In this study, the role of Sox-4 was examined using human Hep3B and HepG2 cell lines. Sox-4 induction by several apoptotic inducer such as A23187 $\left(\mathrm{Ca}^{2+}\right.$ ionophore) and etoposide (topoisomerase II inhibitor) and Sox-4 transfection into the cells were able to induce apoptosis as observed by the cellular DNA fragmentation. Antisense oligonucleotide of Sox-4 inhibited the induction of Sox-4 expression and blocked the formation of DNA fragmentation by $\mathrm{PGA}_{2}$ and $\Delta^{12}-P_{G} J_{2}$ in Hep3B and HepG2 cells. Sox-4-induced apoptosis was accompanied with caspase-1 activation indicating that caspase cascade was involved in this apoptotic pathway.

These results indicate that Sox-4 is involved in Hep3B and HepG2 cells apoptosis as an important apoptotic mediator.
\end{abstract}

Keywords: Sox-4, $\mathrm{PGA}_{2}, \Delta^{12}-\mathrm{PGJ}_{2}$, apoptosis

\section{Introduction}

Many Sox (SRY-HMG box containing) proteins are assumed to be involved in the regulation of developmental stages of several distinct tissues (Uwanogho et al., 1995: Schilham et al., 1998: Southard-Smith et al., 1998) and nervous system in mammals (Prior and Walter, 1996: Jay et al., 1997). Unlike other Sox family proteins, Sox-4, a transcription factor, contains serine-rich trans-activation domain in the C-terminus and is selectively expressed in brain, heart and testis of fetus mice (van de Wetering et al., 1993: Schilham et al., 1997). In adult mice, Sox-4 is also known to be present in the thymus and gonads and is important for early B-cell differentiation (Schilham et al., 1997). Recently, the significant functions of Sox-4 gene have been reported by the gene disruption experiment. The mutation of Sox-4 in the germ line of mice leads to premature death specifically at 14 th embryonic day due to improper development of the valves in the outflow tract of the heart (Schilham et al., 1996). However, little is known about the target genes of Sox-4 proteins and hence about their actual pathophysiological function.

Cyclopentenone prostaglandins(PGs) such as $\mathrm{PGA}_{2}$ and $\Delta^{12}-P G J_{2}$ have antineoplastic effects on the growth of various tumor cells with characteristic morphological and biochemical findings of apoptosis (Fukshima et al., 1994: Lee et al., 1995: Ahn et al., 1998). The expression of genes and their products such as p53, c-myc and heat shock 70 are up- or down-regulated by presence of $\mathrm{PGA}_{2}$ and $\Delta^{12}-\mathrm{PGJ}_{2}$ in human hepatocarcinoma cells. And these genes and their products serve as a positive or negative regulator in $\mathrm{PGA}_{2}$ and $\Delta^{12}-\mathrm{PGJ}_{2}$ induced apoptotic pathway in human hepatocarcinoma cells (Lee et al., 1995: Ahn et al., 1998). When Hep3B cells were exposed to $P G A_{2}$ and $\Delta^{12}-P G J_{2}$, the expression of Sox-4 was specifically increased (Ahn et al., 1999). But the precise pathophysiological role of Sox-4 during tumor cells apoptosis is not well understood.

In this study, we found that the expression of Sox-4 induced by apoptotic inducers such as A23187 $\left(\mathrm{Ca}^{2+}\right.$ ionophore) and etoposide (topoisomerase II inhibitor) in Hep3B and HepG2 cells and transient Sox-4 expression alone induced apotosis mediated by caspase-1. Antisense to Sox-4 cDNA blocked the DNA fragmentation by $\mathrm{PGA}_{2}$ and $\Delta^{12}-P J_{2}$ in Hep3B and HepG2 cells, supporting their involvement in $\mathrm{PGA}_{2}$ and $\Delta^{12}-\mathrm{PGJ}_{2}$ induced apoptotic pathway.

\section{Materials and Methods}

\section{Reagents}

$\mathrm{PGA}_{2}$ was purchased from Sigma Chemical Co. (St. Louis, Mo, USA) and $\Delta^{12}-P J_{2}$ was from BioMol (Plymouth 
Meeting, PA, USA). The human hepatocarcinoma cell lines, Hep3B and HepG2 were obtained from American Type Culture Collection (ATTC, Rockville, MD, USA). Transient expression vector pCDM8 was from Invitrogen (Carlsbad, CA, USA). Antisera to Sox-4 were raised against synthetic peptides derived from the corresponding sequence to amino acid residues, 145-158.

\section{Cell culture condition and treatments}

Hep3B and HepG2 cells were grown in RPMI 1640 medium containing $10 \%$ heat-inactivated fetal bovine serum (Gibco Laboratories, Grand Island, NY, USA), penicillin (100 unit/ml) and streptomycin $(100 \mathrm{mg} / \mathrm{ml})$. Cells were plated at a density of $2 \times 10^{5} \mathrm{cells} / \mathrm{ml}$ on a 6well culture plate and incubated in $37^{\circ} \mathrm{C}, 5 \% \mathrm{CO}_{2}$ incubator. Treatments were performed on exponentially growing subconfluent cells.

\section{Determination of DNA fragmentation}

DNA fragmentation was detected by agarose gel electrophoresis as described previously (Ahn et al., 1999). Cells were washed with phosphate buffered saline (PBS) and incubated in digestion buffer $(10 \mathrm{mM}$ Tris- $\mathrm{HCl}, \mathrm{pH} 7.4,100 \mathrm{mM} \mathrm{NaCl}, 25 \mathrm{mM}$ EDTA, $0.2 \mathrm{mg}$ proteinase $\mathrm{K}, 1 \%$ sarkosyl) at $45^{\circ} \mathrm{C}$ for $3 \mathrm{~h}$. After the addition of $2 \mathrm{ml}$ RNase $A(10 \mathrm{mg} / \mathrm{ml})$, the DNA containing mixture was placed in $37^{\circ} \mathrm{C}$ water bath for $1 \mathrm{~h}$ and extracted with an equal volume of phenol/chloroform/ isoamyl alcohol (25:24:1). The isolated DNA was loaded into $1.8 \%$ agarose gel. After eletrophoresis, the gel was stained with ethidium bromide.

\section{Immunoblot analysis}

Proteins from control and PGs-stimulated cells were solubilized by gel-running buffer $(0.25 \mathrm{M}$ Tris- $\mathrm{HCl}, \mathrm{pH}$ $6.8,1 \%$ SDS, $20 \%$ glycerol, $5 \% \beta$-mercaptoethanol, 0.02 $\%$ bromophenol blue). Samples were fractionated on 10 or $15 \%$ SDS-polyacrylamide gels and then transferred to nitrocellulose membrane by electroblotting. After blocking with $5 \%$ none-fat dry milk in PBS, the membrane was incubated for $2 \mathrm{~h}$ at room temperature with antibodies specific to Sox-4 and caspase-1. Following washing with PBS containing $0.2 \%$ Tween 20 , membrane was incubated with the blocking solution containing the goat anti-rabbit IgG peroxidase conjugate. After washing with PBS (three times for 15 min each), the proteins were detected using ECL-western blot detection kit (Amersham, Buckinghamshire, England).

\section{Cell death detection by ELISA}

For evaluation of apoptosis, a cell death detection ELISA kit (Cell Death Detection ELISA ${ }^{\text {PLUS }}$, Boehringer Mannheim, Mannheim, Germany) was used according to the manufacturers instruction. Briefly, 12, 24 and 48 $\mathrm{h}$ after transfection with Sox-4 vector (pCDM8), cells were washed with PBS. The cells were lysed in $200 \mu \mathrm{l}$ of lysis buffer and centrifuged. Cell supernatants were assayed for apoptosis using the Cell Death Detection Kit. The reaction was developed with the anti-DNAperoxidase system and development of color was measured at $405 \mathrm{~nm}$ with reference wavelength of 490 $\mathrm{nm}$. Assays were performed at least three times.

\section{Transfection}

Hep3B and HepG2 cells were transfected with $5 \mu \mathrm{g}$ of empty expression vector or pCDM8-Sox-4 (2.1 kb) using DOTAP transfection reagent (Boehringer Mannheim). Sox-4 antisense oligomer (5'-CGGCATTGTTGGTTTGC TGCACCAT-3') and sense oligomer (5'-ATGGTGCAGC AAACCAACAATGCCG-3') were synthesized from sequences complementary to the translation starting site. Eighty percent confluent cells were incubated for $6 \mathrm{~h}$ with plasmid DNA mixed with $20 \mu \mathrm{l}$ of DOTAP reagent in serum-free medium at $37^{\circ} \mathrm{C}$ in $5 \% \mathrm{CO}_{2}$ incubator.

\section{Results}

\section{PGs induced the Sox-4 expression in Hep3B and HepG2 cells}

Previously we reported that when Hep3B cells were treated with $20 \mu \mathrm{g} / \mathrm{ml}$ of $\mathrm{PGA}_{2}$ for $24 \mathrm{~h}$, the expression of Sox-4 increased in a dose and time dependent manner. Sox-4 transcription level was elevated closely 10-fold in comparison with the control in Hep3B cells (Ahn et al., 1999). Consistent with these results of the Sox-4 expression (Figure 1), the immunoblot with the anti-Sox-4 antibody showed the increased Sox-4 protein (approximately $48 \mathrm{kDa}$ ) in both Hep3B(Figure $1 \mathrm{~A}$ ) and HepG2 cells treated with $\mathrm{PGA}_{2}$ and $\Delta^{12}-\mathrm{PGJ}_{2}$. (Figure 1B). The Sox-4 protein began to increase after $12 \mathrm{~h}$ and reached the maximum level at $24 \mathrm{hr}$ in both cell lines. The expression of Sox-4 was also induced by several apoptotic agents such as A23187 ( $\mathrm{Ca}^{2+}$ ionophore, $1 \mathrm{ug} /$ $\mathrm{ml}$ ) and etoposide (topoisomerase II inhibitor, $5 \mathrm{ug} / \mathrm{ml}$ ) exposure to Hep3B(Figure 2A) and HepG2 cells(Figure 2B).

\section{Effect of Sox-4 expression on apoptosis}

To investigate the possible role of Sox- 4 in modulating the PG-mediated apoptosis, we have developed human hepatoma cell lines expressing the Sox-4 protein. The cells were transiently transfected with the pCDM8-Sox-4 plasmid based up on CMV(cytomegalovirus) immediated early gene promoter. After transfection, the expression of Sox-4 was multiplied by five fold at $36 \mathrm{~h}$ in Hep3B cells (Figure 3). HepG2 cells also showed an increase in the expression of Sox-4 which developed up to eight folds at $36 \mathrm{~h}$ under the same condition (Figure 3 ).

The relative level of apoptotic activity in Hep3B and 
A

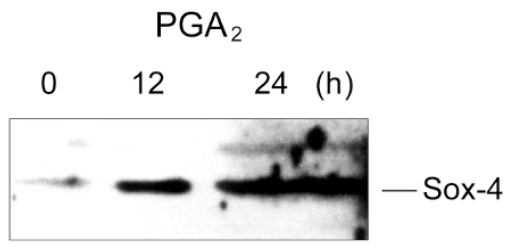

B

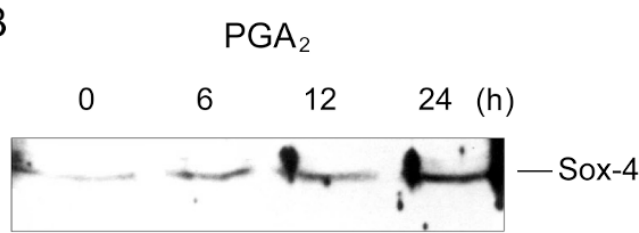

$\Delta^{12}-\mathrm{PGJ}$
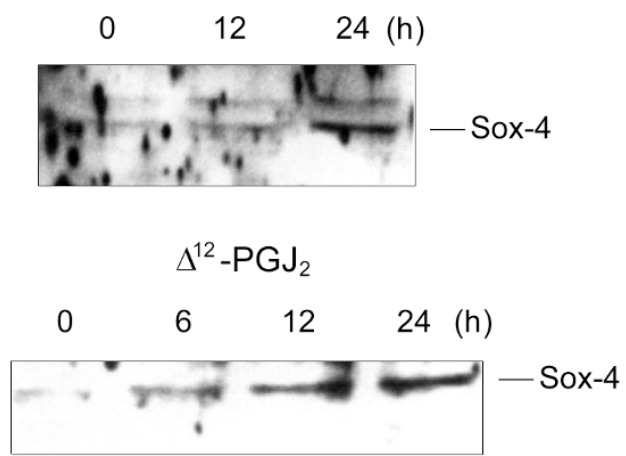

Figure 1. Immunoblot analysis of Sox-4 in Hep3B and HepG2 cells exposed to $P G A_{2}$ and $\Delta^{12}-P G J_{2}$. The cells were exposed to $P G A_{2}(20 \mu g / m l)$ and $\Delta^{12}$. $\mathrm{PGJ}_{2}(5 \mu \mathrm{g} / \mathrm{ml})$ for indicated time periods, and the expression levels of Sox-4 were studied by immunoblot analysis. Control lane $(0 \mathrm{~h})$ is untreated cells. $A$, Hep3B cells; B, HepG2 cells.

A

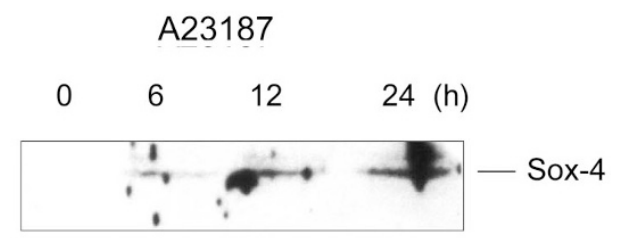

B

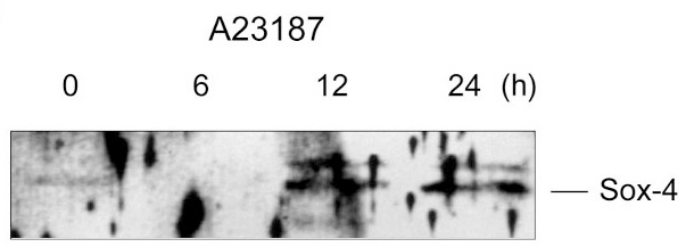

Etoposide

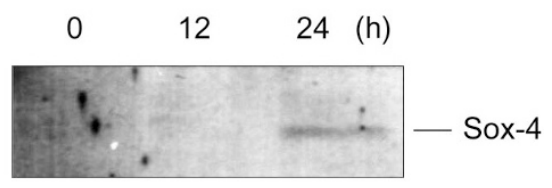

Etoposide

$0 \quad 12 \quad 24(h)$

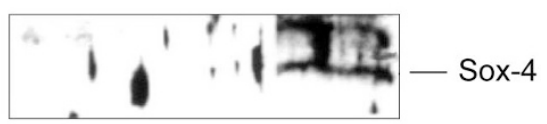

Figure 2. Immunoblot analysis of Sox-4 In Hep3B and HepG2 cells exposed to A23187 and etoposide. The cells were exposed for each time point with presence or absence of $A 23187(1 \mu \mathrm{g} / \mathrm{ml})$ and etoposide $(5 \mu \mathrm{g} / \mathrm{ml})$ and the expression levels of Sox-4 were detected by immunoblot analysis. Control lane $(0 \mathrm{~h})$ shows untreated cells. A, Hep3B cells; B, HepG2 cells.

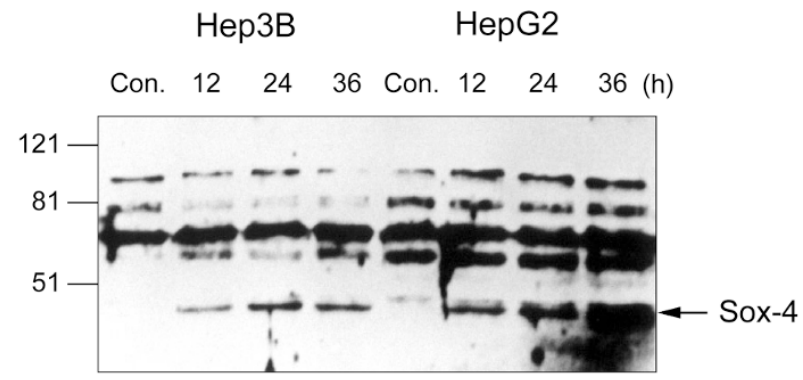

Figure 3. Western blot analysis of Hep3B and HepG2 cells transient transfected with pCDM8-Sox-4. Coding region of Sox-4 CDNA (1.34 kb) was inserted into pCDM8 expression vectors. Purified DNA $(5 \mu \mathrm{g})$ of pCDM8 expression vector containing Sox-4 CDNAs was transfected into Hep3B and HepG2 cells using DOTAP as described. Whole cells were harvested at 12 , 24 and $36 \mathrm{~h}$ after the start of the transfection and analyzed by Western blot.

HepG2 cells transfected with the pCDM8-Sox-4 or control vector was quantified by cell death detection ELISA kit and determined by counting the numbers of apoptotic cells. Approximately $40 \%$ of the transfected cells with the pCDM8-Sox-4 were dead at $24 \mathrm{~h}$ posttransfection. As shown in Figure $4 \mathrm{~A}$, only $40 \%$ of Hep3B/Sox-4 cells were sustained upon overexpression of Sox-4 at $24 \mathrm{~h}$, and similarly, only $62 \%$ of HepG2/Sox4 cells survived upon overexpression of Sox-4 at $24 \mathrm{~h}$ (Figure 4B). In contrast, pCDM8 vector alone did not have an impact on Hep3B and HepG2 cell viability under the same experimental condition (Figure 4A, $4 \mathrm{~B})$.

The ability of Sox-4 to induce apoptosis was confirmed by the DNA fragmentation. Total cellular genomic DNA isolated from pCDM8-Sox-4-transfected Hep3B and HepG2 cells were separated on 1.8\% agarose gels. The transfected cells with the pCDM8Sox-4 plasmid caused DNA fragmentation at $24 \mathrm{~h}$ posttransfection in Hep3B cells, while the genomic DNA of HepG2 showed significant DNA degradation after $48 \mathrm{~h}$ later (Figure 5).

\section{Effects of Sox-4 antisense oligonucleotide on $\mathrm{PGA}_{2}$ - induced apoptosis}


A

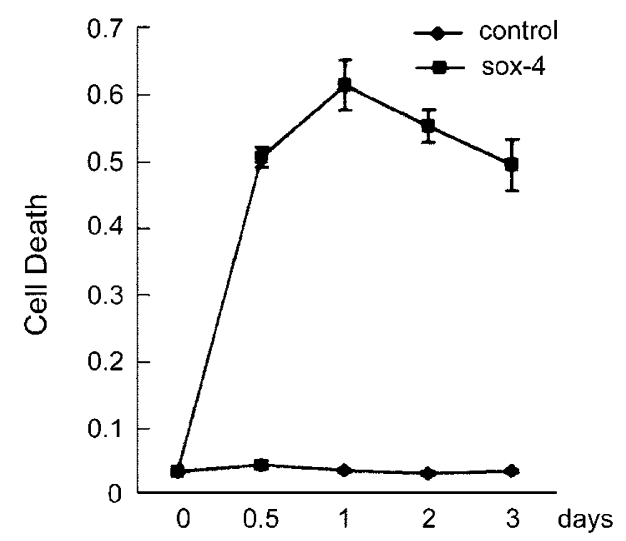

B

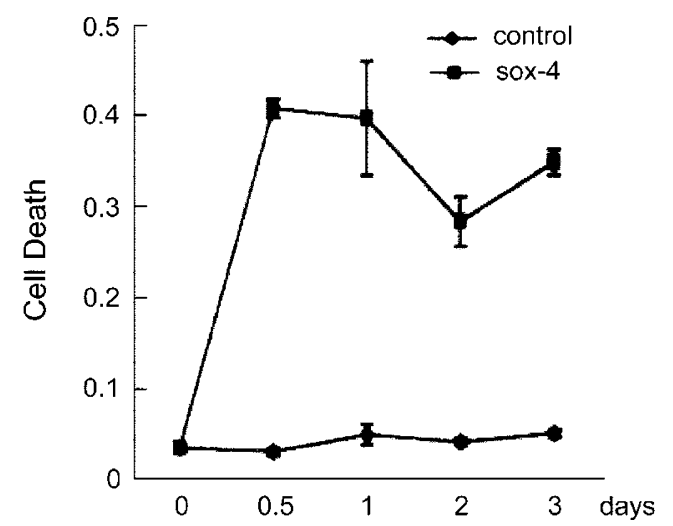

Figure 4. Sox-4 induced apoptosis in Hep3B and HepG2 cells after transfection of pCDM8-Sox-4. $1 \times 10^{3}$ cells/well were seeded into 96 well culture dishes and incubated at $37^{\circ} \mathrm{C}, 5 \% \mathrm{CO}_{2}$ after pCDM8-Sox-4 transfection for $12,24,48$ and $72 \mathrm{~h}$, respectively. Percentage of apoptotic cells were measured by modified Cell Death Detection ELISA at $405 \mathrm{~nm}-490$ nm. A, Hep3B cells; B, HepG2 cells.

A

B

Con. $12 \quad 24 \quad 48(h)$

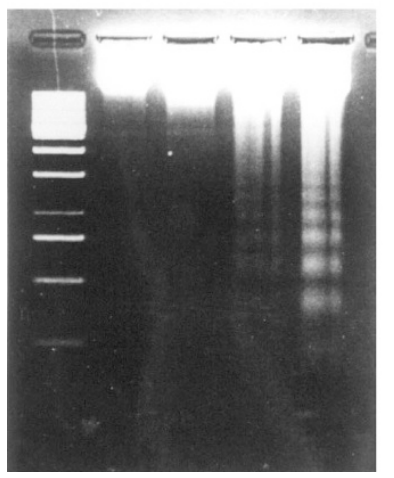

Con. $12 \quad 24 \quad 48$ (h)

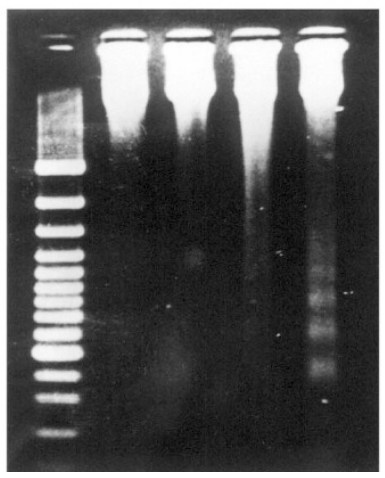

Figure 5. Time course of DNA fragmentation in Hep3B and HepG2 cells by Sox-4 overexpression. Whole cells were harvested at 12, 24 and $48 \mathrm{~h}$, respectively after the start of the pCDM8-Sox-4 transfection and genomic DNA were extracted from the cells. A, Hep3B cells; B, HepG2 cells.

To determine whether Sox-4 was directly involved in the induction of apoptosis, we used antisense oligonucleotide to diminish the function of this gene. Whereas the sense
A

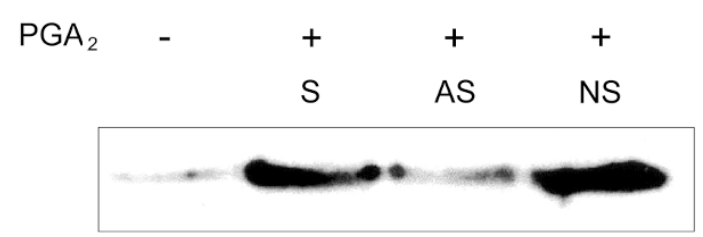

$B$

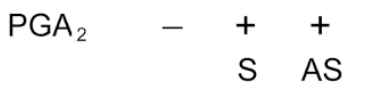

$\mathrm{C}$

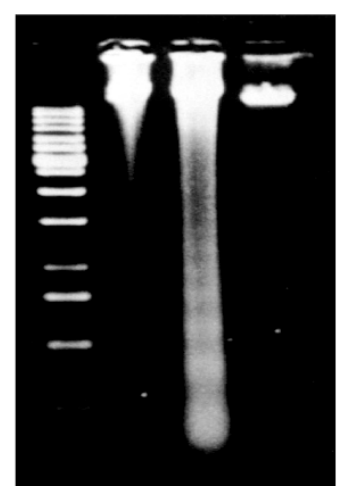

$\mathrm{PGA}_{2}-\quad+\quad+$

$S$ AS

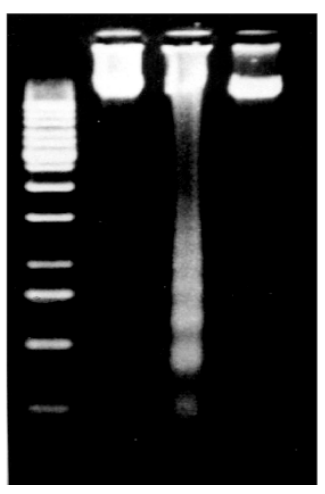

Figure 6. Inhibition of DNA fragmentation by treatment of antisense oligonucleotide corresponding to Sox-4. A. Western blot analysis for the production of Sox-4 in Hep3B cells treated with the sense, antisense and nonsense Sox-4 oligonucleotides. B and C. Hep3B and HepG2 cells were treated with either antisense or sense oligonucleotides corresponding to the translation start region of human Sox-4 and DNA fragmentation was induced by $\mathrm{PGA}_{2}(20 \mu \mathrm{g} / \mathrm{ml})$. DNA fragmentation was analyzed on agarose gels (1.8\%) stained with ethidium bromide. B, Hep3B cells; C, HepG2 cells.

oligonucleotide showed no effects on the induction of Sox-4 expression, antisense oligonucleotide of Sox-4 inhibited the induction of Sox-4 expression as well as the DNA fragmentation in $\mathrm{PGA}_{2}$-treated Hep3B cells (Figure 6A, B). The similar result was obtained from the HepG2 cell (Figure 6C). These results demonstrates that the induction of Sox-4 may directly modulate the $\mathrm{PGA}_{2}$ - mediated apoptosis in Hep3B and HepG2 cells.

\section{Sox-4 induced apoptosis is inhibited by the Caspase-1 like inhibitor Ac-YVAD-CHO}

To test the ability of the caspase inhibitors in Sox-4induced apoptosis, we incubated the Hep3B and HepG2 cells overexpressing Sox-4 with different concentrations of ICE inhibitor Ac-YVAD-CHO, Ich-1 inhibitor z-DVAD-FMK and CPP32/Yama inhibitor AcDEVD-CHO.

As shown in Figure $7 \mathrm{~A}$, approximately $40 \%$ and $90 \%$ of the DNA fragmentation was inhibited by $50 \mu \mathrm{M}$ of AcYVAD-CHO and $100 \mu \mathrm{M}$ of Ac-YVAD-CHO, respectively. Also, $100 \mu \mathrm{M}$ of z-DVAD-FMK inhibited $80 \%$ of the DNA fragmentation appeared by Sox-4-induced apoptosis in Hep3B cells. Meanwhile, $100 \mu \mathrm{M}$ of Ac-DEVD-CHO showed no significant inhibition of Sox-4-induced 


\begin{tabular}{|c|c|c|c|c|c|c|c|c|c|c|}
\hline & & & 100 & & & 50 & & & 100 & \\
\hline AC-YVAD-CHO & - & - & $+\quad-$ & - & + & - & - & + & - & - \\
\hline Z-DVAD-FMK & - & - & $-\quad+$ & - & - & + & - & - & + & - \\
\hline AC-DEVD-CHO & - & - & $-\quad-$ & + & - & - & + & - & - & + \\
\hline Sox-4 & - & + & $-\quad-$ & - & + & + & + & + & + & + \\
\hline
\end{tabular}

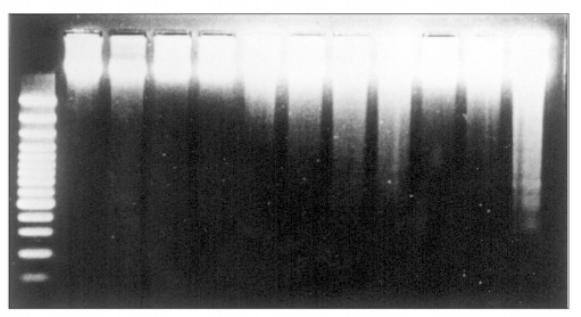

B
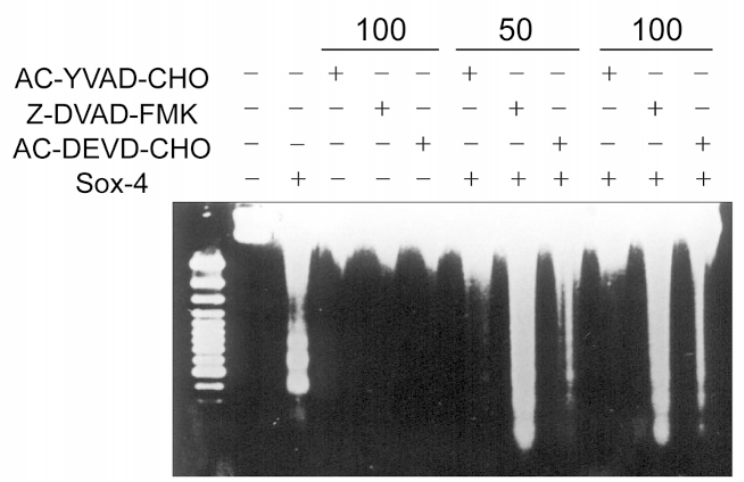

Figure 7. Inhibition of Sox-4-induced apoptosis in Hep3B and HepG2 cells by caspase inhibitors. Whole cells $\left(1 \times 10^{5} \mathrm{cells} / \mathrm{ml}\right)$ harvested at $48 \mathrm{~h}$ after the start of the transfection, in presence of caspase inhibitors (each $50 \mu \mathrm{M}$ and $100 \mu \mathrm{M}$ ) and genomic DNA samples were extracted from the cells. The concentrations of each caspase inhibitor tested are indicated in the figure. A, Hep3B cells; B, HepG2 cells

apoptosis in Hep3B cells. In contrast, the Sox-4-induced DNA fragmentation in HepG2 cells was not nearly inhibited by $100 \mu \mathrm{M}$ z-DVAD-FMK and partially inhibited by up to $100 \mu \mathrm{M}$ of Ac-DEVD-CHO (Figure 7B). Similarly, as shown in Hep3B cells, the Sox-4-induced
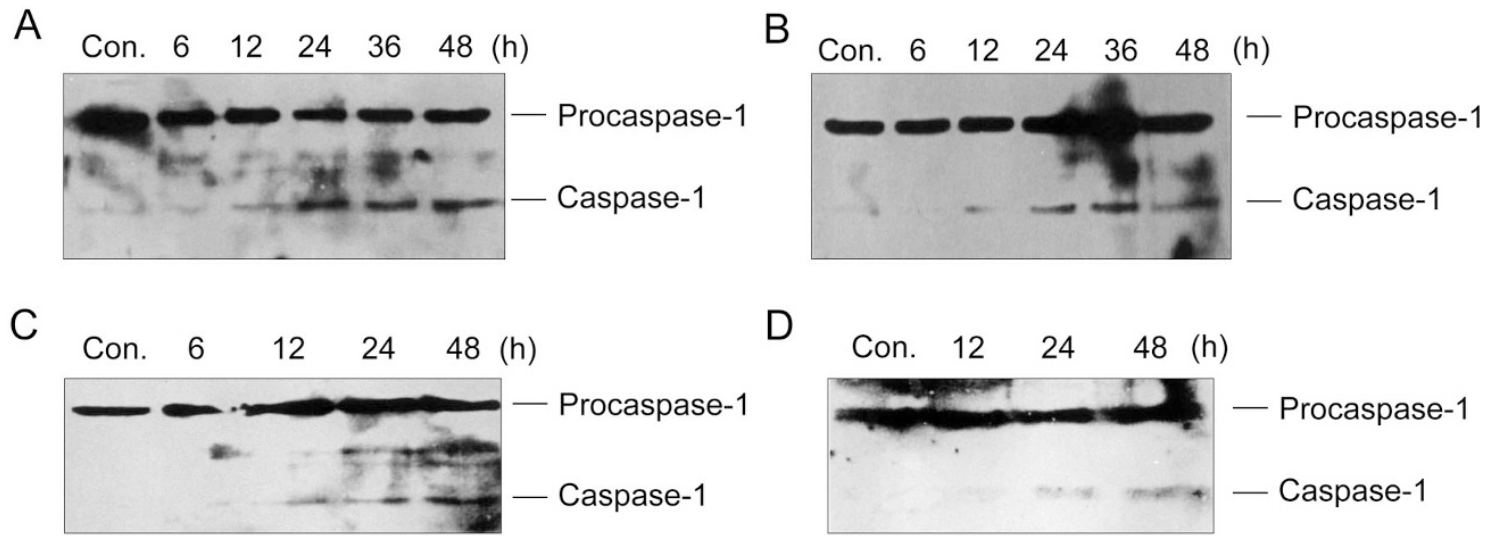

$\mathrm{D}$

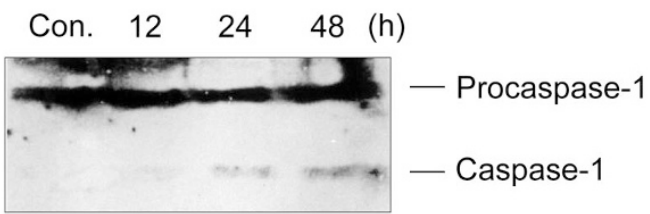

Figure 8. Cleavage of caspase-1 protein in Hep3B and HepG2 cells during Sox-4-induced apoptosis. Hep3B cells were prepared at different incubation times after $\mathrm{PGA}_{2}\left(20 \mu \mathrm{g} / \mathrm{ml}\right.$, Figure 8A), $\Delta^{12}-\mathrm{PGJ}_{2}(5 \mu \mathrm{g} / \mathrm{ml}$, Figure 8B) treatment and Sox-4 overexpression (Figure 8C). Under overexpression of Sox-4, an activation of the caspase-1 was also observed in HepG2 cells(D). Proteins were separated in SDS-PAGE and subsequently immunobloted with anti-caspase-1. 
as a positive or negative mediator in $\mathrm{PGA}_{2}$ and $\Delta^{12}$. $P G J_{2}$ induced apoptosis in tumor cells.

Recent studies revealed that the mutation of Sox$4\left(\right.$ Sox $\left.4^{-/}\right)$in the embryo of mice leads to premature death at 14th embryonic days due to impaired development of the endocardial ridges (Schilham et al., 1996: Ya et al., 1998). In 1998, Southard-Smith et al. reported that premature termination of Sox-10, a member of the Sox family, disrupted neural crest development due to apoptosis in Dom Hirschsprung mouse models. These results add the possibility that Sox genes, including Sox-4, may involved in tumor cell apoptosis by various apoptosis inducing agents.

As previously mentioned, the induction of apoptosis in hepatoma cells by PGs showed characteristic morphological and biochemical findings of apoptosis (Lee et al., 1995: Ahn et al., 1998). Here, we described the increased expression of Sox-4 by $\mathrm{PGA}_{2}$ and $\Delta^{12}-\mathrm{PGJ}_{2}$ treatment in Hep3B and HepG2 cells. The expression of Sox-4 was also increased by several apoptotic inducer such as A23187 $\left(\mathrm{Ca}^{2+}\right.$ ionophore) and etoposide (topoisomerase II inhibitor). During apoptosis of Hep3B cells and HepG2 cells Sox-4 were observed to be overexpressed. When Hep3B and HepG2 cells were transiently transfected with pCDM8-Sox-4, only $40 \%$ of Hep3B/Sox-4 cells and $62 \%$ of HepG2/Sox-4 cells survived upon overexpression of Sox-4 at $24 \mathrm{~h}$, as well. The transfected cells with pCDM8-Sox-4 plasmid caused DNA fragmentation at $12 \mathrm{~h}$ and $24 \mathrm{~h}$ in Hep3B and HepG2 cells respectively and antisense oligonucleotide corresponding to the Sox-4 translation starting site completely inhibited the $\mathrm{PGA}_{2}$ and $\Delta^{12}-\mathrm{PGJ}_{2}$ induced apoptosis.

There are two kinds of apoptotic pathway known in tumor cells induced by chemotherapeutic agents. One is AlF-dependent and the other is cytochrome Cdependent pathway (Hunot S. and Flavell R.A. 2001). Examination of the Sox-4-induced apoptosis path showed that Sox-4-induced DNA fragmentation was inhibited by Ac-YVAD-CHO, a universal inhibitor of caspase-1 like protease and processing of caspase-1 from its inactivate to active form. Such result suggests that the caspase cascade, specially caspse- 1 is involved in Sox-4-induced apoptosis. Gagliardini et al. hypothesized that caspase- 1 is involved in apoptosis in Dorsal root ganglion neurons in vertebrates (Miura et al., 1993: Gagliardini et al., 1995). Caspase-1 was found to be involved in the apoptosis of mammary epithelial cells and interferon regulatory factor-1-dependent Tlymphocyte apoptosis (Boudreau et al., 1995: Tamura et al., 1995). These results provide evidence that caspase1 like protease plays a critical role in Sox-4-induced apoptosis. Alternatively, caspase- 1 and the rest of caspase family may act as an activator of caspase-2 and caspase-3.

However, an inhibitor of caspase-3 like protease (Ac-
DEVD-CHO) did not inhibit Sox-4-mediated apoptosis in Hep3B cells. We also could not detect any proteolytic activity capable of cleaving pro-capase-3 in Hep3B cell. But, an inhibitor of caspase-3 like proteases partially inhibited Sox-4-mediated apoptosis in HepG2 cells under the same condition. Furthermore, we found that the pro-caspase- 3 is processed after $P G A_{2}$ and $\Delta^{12}$ $P G J_{2}$ treatment and Sox-4 overexpression (data not shown). These results demonstrated that a Sox-4mediated activation of caspase- 3 is not observed in Hep3B cells, suggesting that Sox-4-mediated caspase3 activation is a cell-type specific.

Conclusively, our data demonstrated that Sox-4 is a positive regulator of Hep3B and HepG2 cells apoptosis induced by $P G A_{2}$ and $\Delta^{12}-P J_{2}$, and its pathway might go through activation of caspase-1.

\section{Acknowledgements}

This study was partially supported by a grant of the Korea Health $21 \mathrm{R}$ and D Project, Ministry of Health and Welfare, Republic of Korea (HMP-99-B-0-2002) and by a grant of the KOSEF (Korea Science and Engineering Foundation), Republic of Korea (2000-2-20800-008-3).

\section{References}

Ahn SG, Jeong SY, Rhim H, Choi JY and Kim IK. Identification of CDNAs for Sox-4, an HMG-box protein, and a novel human homolog of yeast splicing factor SSF-1 differentially regulated during apoptosis induced by prostaglandin $(P G) A_{2} / \Delta^{12}-P G J_{2}$ in Hep3B cells. Biochem Biophys Res Commun 1999;260:216-21

Ahn SG, Jeong SY, Rhim HS and Kim IK. The role of c-Myc and heat shock protein 70 in human hepatocarcinoma Hep3B cells during apoptosis induced by prostaglandin (PG) $A_{2} / \Delta^{12}$. $\mathrm{PGJ}_{2}$. Biochim Biophysi Acta 1998;1448:115-25

Boudreau N, Sympson CJ, Werb Z and Bissell MJ. Suppression of ICE and apoptosis in mammary Epithelia cells by extracellular matrix. Science 1995;267:891-93

E.Michelle S, Lidia K and William JP. Sox10 mutation disrupts neural crest development in Dom Hirschsprung mouse model. Nature Gen 1998;18:60-64

Enari $\mathrm{M}$, Hug $\mathrm{H}$, and Nagata $\mathrm{S}$. Involvement of an ICE-like protease in Fas-mediated apoptosis. Nature 1995;375:78-81

Enari M, Talanian RV, Wong WW and Nagata S. Sequential activation of ICE-like and CPP32-like proteases during Fasmediated apoptosis. Nature 1996;380:723-26

Fukushima M, Sasaki $\mathrm{H}$ and Fukushima S. Prostaglandin $\mathrm{J}_{2}$ and related compounds. Mode of action in $\mathrm{G}_{1}$ arrest and preclinical results. Ann NY Acad Sci 1994;744:161-65

Gagliardini V, Fernandez PA, Lee RKK, Drezler HCA, Rotello RJ, Fishman $M C$ and Yuan $J$ Prevention of vertebrate neuronal death by the CrmA gene. Science 1995;263:826-28 
Holbrook NJ, Carlson SG, Choi AMK and Fargoli J. Induction of HSP70 gene expression by the antiproliferative prostaglandin $\mathrm{PGA}_{2}$ : a growth-dependent response mediated by activation of heat shock transcription factor. Mol Cell Biol 1992;12:152834

Hunot S and Flavell RA. Apoptosis: Death of a monopoly? Science 2001;292:865-66

Jay P, Sahly I, Goze C, Taviaux S, Poulat F, Couly G, Abitbol $\mathrm{M}$ and Berta P. SOX22 is a new member of SOX gene family, mainly expressed in human nervous tissue. Human Molecular Genomics 1997;6:1069-77

Kaufmann SH. Apoptosis: Pharmacological implications and therapeutic opportunities. 1997, Academic press, San Diego, CA.

Kim IK, Lee JH, Kim HS, Kwon OJ and Shim BS. A novel function of haptoglobin: haptoglobin-haemoglobin complex induced apoptosis of hepatocarcinomatous Hep3B cells. Scand J Clin Lab Invest 1995;55:529-35

Lee JH, Kim HS, Jeoung SY and Kim IK. Induction of p53 and apoptosis by $\Delta^{12}-\mathrm{PGJ}_{2}$ in human hepatocarcinoma SK-Hep-1 cells. FEBS Lett 1995;368:348-52

Marco WS and Hans C. HMG box containing transcription factors in lymphocyte differentiation. Sem Immun 1998; 10:127-32

Miura M, Zhn H, Rotello R, Hartwieg EA and Yuan J. Introduction of apoptosis in Fibroblasts by IL-1 $\beta$-converting enzyme, a mammalian homolog of the $C$. elegans cell death gene ced-3. Cell 1993;75:653-60

Molle WV, Libert C, Fiers W and Brouckaert P. $\alpha_{1}$-Acid glycoprotein and $\alpha_{1}$-Antitrypsin inhibit TNF-induced but not anti-Fas-induced apoptosis of hepatocytes in mice. J Immunol 1997;159:3555-64

Nicholson DW, Ali NA, Thornberry JP, Vaillsncourt CK, Ding M, Gallant Y, Gareau PR, Griffin M, Labaelle TA, Lazebnik YA, Munday NA, Raju SM, Smulson ME, Yamin TT, Yu VL and Miller DK. Identification and inhibition of the ICE/CED-3 protease necessary for mammalian apoptosis. Nature 1995; 376:37-43

Prior HM and Walter MA. SOX genes: architects of development. Molecular Medicine 1996;2:405-12

Santoro MG, Geraci E and Amici C. Prostaglandins with antiproliferative activity induce the synthesis of heat shock protein in human cells. Proc Natl Acad Sci USA 1989; 86:8407-11

Schilham MW, Moerer P, cumano A, Clevers H. Sox4 facilitates thymocyte differentiation. Eur J Immunol 1997; 27:1292-99

Schilham MW, Oosterwegel MA, Moerer P, Ya P, de Boer PAJ, van de Wetering $M$, Verbeek $S$, Lamers $W H$, Kruisbeek AM, Cumano A, Clevers $H$. Defects in cardiac outflow tract formation and pro-B-lymphocyte expansion in mice lacking Sox-4. Nature 1996;380:711-14

Southard-Smith EM, Kos L and Pavan W. Sox10 mutation disrupts neural crest development in Dom Hirschsprung mouse model. Nature Gen 1998;18:60-64

Tamura T, Ishihara M, Lamphier MS, Tanaka N, Oishi I, Aizawa S, Matsuyama T, Mak TW, Taki S and Taniguchi T. And IRF-1 dependent pathway of DNA damage-induced apoptosis in mitogen-activated T lymphocytes. Nature 1995; 376:596-99

Tewari $\mathrm{M}$ and Dixit VM. Fas- and tumor necrosis factorinduced apoptosis is inhibited by the poxvirus crmA gene product. J Biol Chem 1995;270:3255-60

Thronberry NA and Lazebnik Y. Caspase: Enemies within. Science 1998;281:1312-16

Uwanogho D, Rex M, Cartwright EJ, Pearl G, Healy C, Scotting PJ and Sharpe PT. Embryonic expression of the chicken Sox2, Sox3 and Sox11 genes suggests an interactive role in neuronal development. Mech Dev 1995;49(1-2):23-36

van de Wetering $M$, Oosterwegel $M$, van Norren $K$ and Clevers H. Sox-4, an Sry-like HMG-box protein, is a transcriptional activator in lymphocytes. EMBO J 1993; 12:3847-54

Ya J, Schilham MW, de Boer PAJ, Moorman AFM, Clevers H and Lamers WH. Sox4-deficiency syndrome in mice is an animal model for common trunk. Circ Res 1998;83:986-94 